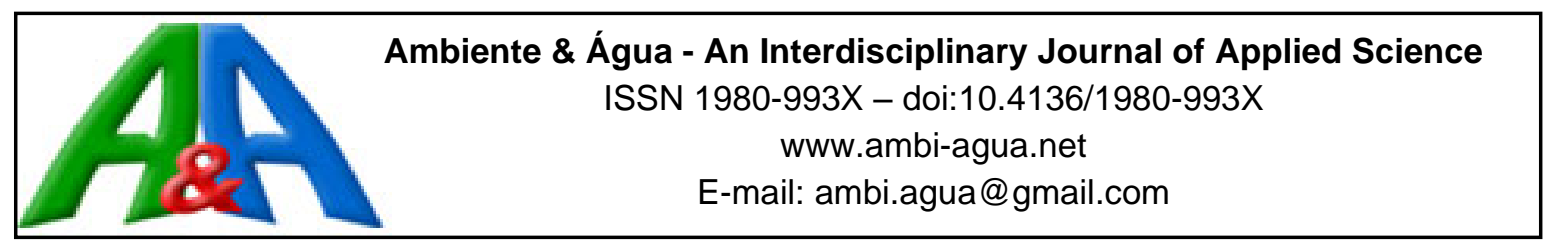

\title{
Variability of soil physical and hydraulic properties along a toposequence in the coastal lowlands of Rio de Janeiro
}

\author{
ARTICLES doi:10.4136/ambi-agua.2579 \\ Received: 15 May 2020; Accepted: 18 Dec. 2020 \\ João Henrique Gaia-Gomes ${ }^{1}$; Carlos Roberto Pinheiro Junior ${ }^{1}$ (D); \\ Marcos Gervasio Pereira ${ }^{1 *}$; Wilk Sampaio de Almeida ${ }^{2}$; \\ Geuzimar Terração Silva1 ${ }^{10}$
}

\begin{abstract}
${ }^{1}$ Instituto de Agronomia. Departamento de Solos. Universidade Federal Rural do Rio de Janeiro (UFRRJ), Rodovia BR-465, km 7, CEP: 23897-000, Seropédica, RJ, Brazil.

E-mail: gaia.gomes.pgeaamb@gmail.com, robertojrpinheiro@gmail.com, terracaoufrrj@gmail.com ${ }^{2}$ Instituto Federal de Educação, Ciência e Tecnologia de Rondônia (IFRO), Rodovia RO-257, km 13, CEP: 76870-000, Zona Rural, Ariquemes, RO, Brazil. E-mail: wilk.almeida@ifro.edu.br *Corresponding author. E-mail: mgervasiopereira01@gmail.com
\end{abstract}

\begin{abstract}
Soil physical and hydraulic properties are interdependent, and soil-use planning and management are complicated by the high variability of these attributes. The current study assessed the variability of physical and hydraulic properties of soils along a toposequence located in a forest fragment under spontaneous regeneration in the coastal lowlands of Rio de Janeiro. Four soil profiles were selected, and samples were collected from surface and subsurface horizons for determination of moisture content, bulk density, macroporosity, microporosity, hydraulic conductivity, texture, and soil resistance to penetration (measured using benchtop and field penetrometers). Exploratory and principal component analyses were performed, and descriptive parameters and Pearson's correlation coefficients were calculated. In A horizons of profiles 3 (Planossolo) and 4 (Gleissolo), clay contents ranged from 59.0 to $577.0 \mathrm{~g} \mathrm{~kg}^{-1}$, moisture contents from 1.5 to $16.4 \%$, and microporosity from 10.4 to $46.2 \%$, respectively. Field- and laboratory-measured penetration resistances showed a stronger association with profile 1 (Argissolo); however, values were not sufficiently high to limit root development. The variability in soil physical and hydraulic properties in short slopes is high, mainly in terms of hydraulic conductivity, moisture, microporosity, and clay content. The greater variability of soil physical and hydraulic properties in lowland is attributed to clay and silt fractions, microporosity, and moisture content. The increment in clay content with depth increases bulk density and resistance to root penetration.
\end{abstract}

Keywords: edaphic attributes, soil-landscape relationship, soil quality indicators.

\section{Variabilidade de atributos físico-hídricos em uma topossequência na Baixada Litorânea Fluminense}

\section{RESUMO}

Os atributos físico-hídricos do solo são interdependentes e o planejamento e o manejo do solo são dificultados devido à alta variabilidade desses atributos. O presente estudo objetivou avaliar a variabilidade dos atributos físico-hídricos em uma topossequência inserida em área de 
regeneração espontânea na Baixada Litorânea Fluminense. Foram selecionados quatro perfis, e nestas coletadas amostras nos horizontes superficiais e subsuperficiais para quantificação dos valores da umidade, densidade do solo, macroporosidade, microporosidade, condutividade hidráulica, granulometria e resistência do solo à penetração (com penetrômetro de bancada e em campo). Foi realizada a análise exploratória e calculados os parâmetros descritivos, o teste de correlação de Pearson e a análise dos componentes principais. Nos horizontes A, o teor de argila variou de 59,0 a $577,0 \mathrm{~g} \mathrm{~kg}^{-1}$, a umidade de 1,5 a $16,4 \%$ e a microporosidade 10,4 a 46,2\%, entre os perfis P3 (Planossolo) e P4 (Gleissolo). A resistência à penetração nos dois métodos esteve mais relacionada com o perfil 1 (Argissolo), entretanto, os valores máximos não restringem o desenvolvimento das raízes. A variabilidade dos atributos físico-hídricos em vertentes de pequeno comprimento é alta, principalmente para os atributos condutividade hidráulica, umidade, microporosidade, e argila do solo. Na baixada a maior variabilidade dos atributos físico-hídricos é explicada pelos atributos argila, microporosidade, silte e umidade. $\mathrm{O}$ incremento de argila em profundidade aumenta a densidade e a resistência do solo à penetração das raízes.

Palavras-chave: atributos edáficos, indicadores de qualidade do solo, relação solo-paisagem.

\section{INTRODUCTION}

Our understanding of water flows in natural and anthropized ecosystems depends on the precise characterization of soil hydrological processes (Alagna et al., 2016; Pavão et al., 2019). Because this type of characterization requires a thorough knowledge of soil physical and hydraulic properties, it is essential to determine the variability of these attributes in the environment. As discussed by several authors (Cambardella et al., 1994; Santos et al., 2016; Pavão et al., 2019; Ferreira et al., 2020), soil formation processes and anthropogenic actions enhance the variability in soil attributes.

It is of fundamental importance that studies involving the characterization of soils and their potential, as well as the environmental weaknesses in view of the different types of use that can occur in the different segments of landscapes that are special to a particular region. Studies of this nature contribute both to the understanding of fragile ecosystems, constantly occurring to environmental degradation, and to future work to characterize coastal plains (Coelho et al., 2010).

When assessing the environmental vulnerability of the coastal plain of Caravelas (BA) as a subsidy to environmental planning, the authors Souza and Vale (2016) concluded that studies like these can be used to guide management policies for coastal areas and contribute to the new occupations and economic and social development are compatible with environmental preservation.

There are several challenges in assessing the variability in soil porosity, particle size, particle size distribution, bulk density, resistance to penetration, least-limiting water range, compression index, aggregate stability, and hydraulic conductivity. According to Oliveira et al. (2015), most limitations arise from the large extension of study sites and the large number of samples and high costs consequently associated with these investigations.

Considering the above-mentioned soil physical attributes, Stefanoski et al. (2013) argued that soil hydraulic conductivity is one of the best indicators of soil quality because it can reveal structural differences between soil profile layers. In a study investigating the physical and hydraulic properties and organic carbon content of an Argissolo under different management systems for 23 years, Hickmann et al. (2012) found that management effects were more pronounced in the surface layer. Ferreira et al. (2020), in investigating the effects of 23 years of direct planting on aggregate formation and soil organic matter in rainy and dry seasons, 
concluded that soil aggregation is a simple, low-cost, repeatable, and easy-to-understand indicator of changes in soil physical conditions.

Despite the importance of soil physical and hydraulic properties to the understanding of major ecosystem processes (Pavão et al., 2019), the variability of these attributes along slopes still requires further investigation. Therefore, this study aimed to assess the variability of soil physical and hydraulic properties along a toposequence in the coastal lowlands of Rio de Janeiro.

\section{MATERIAL AND METHODS}

The study area is located on the campus of the Federal Rural University of Rio de Janeiro, Seropédica, Rio de Janeiro Metropolitan Region, Brazil. The climate is tropical wet and dry (Aw in the Köppen climate classification system), with rainfall events concentrated during November to March. The mean annual precipitation is $1213 \mathrm{~mm}$, and the mean annual temperature is $24.5^{\circ} \mathrm{C}$ (Alvares et al., 2013). The geology of the area is dominated by acidic rocks from the Southern Paraíba Complex, such as gneisses and granites. The region belongs to the coastal plains of Sepetiba Bay, characterized by a slightly undulating relief with small variations in elevation (Muehe et al., 2006).

A toposequence of soils under regenerating Atlantic forest was selected for the study. Four trenches were opened at different locations of the landscape, each spaced about $40 \mathrm{~m}$ apart (Figure 1).

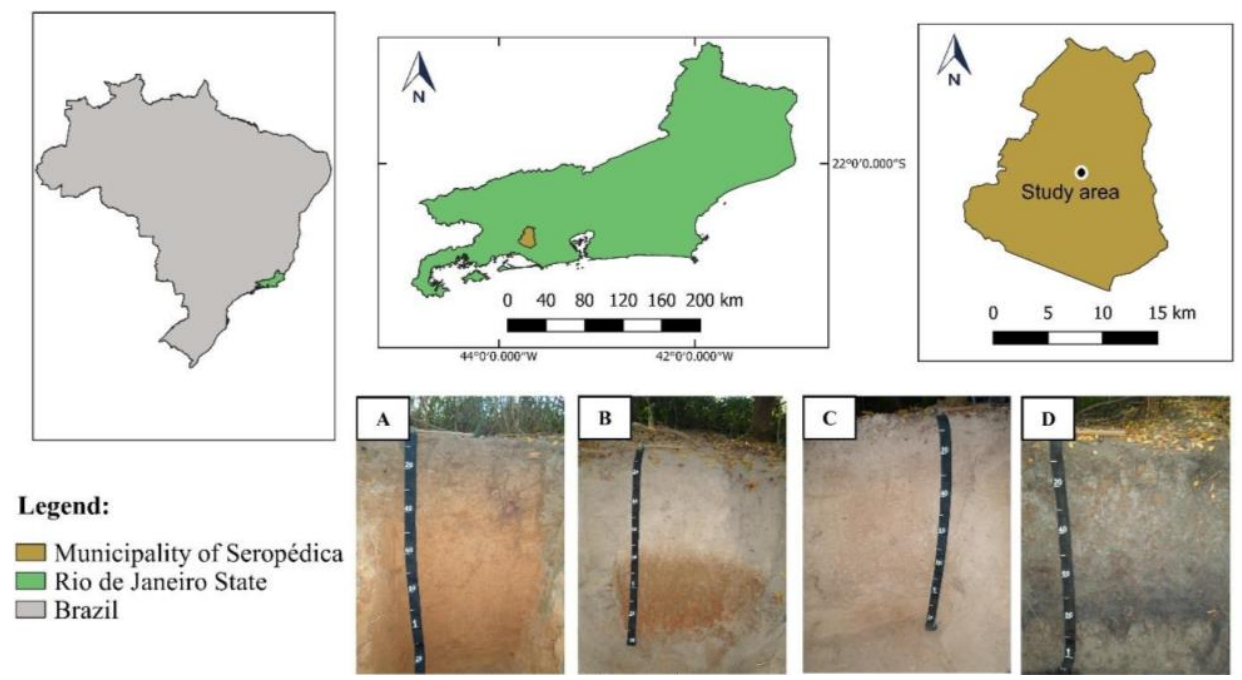

Figure 1. Location map of the study area showing the evaluated soil profiles in the upper (A), middle (B), and lower thirds (C) of the slope and lowland (D).

Morphological characteristics of soil profiles were described according to criteria proposed by Santos et al. (2015), and soil types were classified in accordance with the Brazilian Soil Classification System (Santos et al., 2018) and the general information about sampling sites and soil morphological and textural properties are presented in Table 1.

Disturbed samples were collected from surface and subsurface diagnostic horizons for color, structural, and textural analyses. Four undisturbed samples were collected using an Uhland soil sampler. Sampling depth was defined on the basis of horizon thickness; collections were performed from the central part of the horizon for increased representativeness of soil attributes.

Gravimetric moisture content, bulk density, macroporosity, microporosity, and saturated hydraulic conductivity were determined according to Teixeira et al. (2017). Analysis of soil penetration resistance was performed by two methods using four replications. Laboratory- 
measured penetration resistance was determined using a Tecnal Te-096 benchtop penetrometer, and field-measured penetration resistance was assessed using an impact penetrometer, according to Stolf (1991). Particle size analysis was performed by the pipette method (Teixeira et al., 2017) to determine sand, silt, and clay contents.

Table 1. Morphological and textural properties of soil profiles evaluated in the study.

\begin{tabular}{|c|c|c|c|}
\hline Horizon & Depth $(\mathrm{cm})$ & Moist color & Soil structure \\
\hline \multicolumn{4}{|c|}{ Profile 1 (Argissolo Vermelho-Amarelo, upper third of slope, elevation $42 \mathrm{~m}$, slightly undulating $8 \%$ and well drained) } \\
\hline A & $0-9$ & $5 Y R 3 / 2$ & Strong, fine and medium, granular \\
\hline $\mathrm{AB}$ & $9-18$ & $5 Y R 3 / 3$ & Strong, fine and medium, granular \\
\hline $\mathrm{BA}$ & $18-30$ & $5 Y R 4 / 3$ & Strong, fine, subangular blocky \\
\hline Bt1 & $30-52$ & $5 Y R 4 / 6$ & Strong, fine, subangular blocky \\
\hline $\mathrm{Bt} 2$ & $52-75$ & $5 Y R 4 / 6$ & Strong, fine, subangular blocky \\
\hline Bt3 & $75-102$ & $5 Y R 5 / 4$ & Strong, fine, subangular blocky \\
\hline Bt4 & $102-116^{+}$ & 5YR 5/6 & Strong, fine, subangular blocky \\
\hline \multicolumn{4}{|c|}{ Profile 2 (Argissolo Amarelo, middle third of slope, elevation $41 \mathrm{~m}$, slightly undulating $12 \%$ and moderately drained) } \\
\hline A & $0-7$ & $10 \mathrm{YR} 4 / 2$ & Weak to moderate, fine, granular \\
\hline $\mathrm{AE}$ & $7-17$ & $10 Y R 5 / 2$ & Weak to moderate, fine, granular \\
\hline E1 & $17-44$ & $10 Y R 5 / 4$ & Weak, fine, granular \\
\hline $\mathrm{E} 2$ & $44-80$ & $10 Y R 5 / 4$ & Weak, fine, granular \\
\hline Bt1 & $80-102$ & $10 Y R 5 / 5$ & Moderate, fine, subangular blocky \\
\hline $\mathrm{Bt} 2$ & $102-134^{+}$ & $10 \mathrm{YR} 4 / 6$ & Moderate, fine, subangular blocky \\
\hline \multicolumn{4}{|c|}{ Profile 3 (Planossolo Háplico, lower third of slope, elevation 39 m, slightly undulating 4\% and imperfectly drained) } \\
\hline A1 & $0-14$ & $10 \mathrm{YR} 4 / 2$ & Weak, fine, granular \\
\hline $\mathrm{A} 2$ & $14-31$ & $10 \mathrm{YR} 4 / 2$ & Weak, fine, granular \\
\hline $\mathrm{AE}$ & $31-54$ & 10YR 5/4 & Weak, fine, granular \\
\hline E1 & $54-71$ & $10 Y R 5 / 4$ & Single grain \\
\hline E2 & $71-96$ & $10 Y R 5 / 4$ & Single grain \\
\hline $\mathrm{Bt}$ & $96-128$ & 10YR 6/4 & Moderate, fine, subangular blocky \\
\hline $\mathrm{BC}$ & $128-164^{+}$ & $10 \mathrm{YR} 6 / 2$ & Weak to moderate, fine, subangular blocky \\
\hline \multicolumn{4}{|c|}{ Profile 4 (Gleissolo Háplico, lowland, elevation 38 m, slightly undulating 1\% and poorly drained) } \\
\hline A & $0-7$ & 10YR 3/1 & Strong, very fine, angular blocky \\
\hline $\mathrm{AB}$ & $7-16$ & $10 \mathrm{YR} 4 / 1$ & Strong, very fine, angular blocky \\
\hline $2 \mathrm{Bg} 1$ & $16-41$ & N 5 & Strong, fine, angular blocky \\
\hline $2 \mathrm{Bg} 2$ & $41-55$ & N 5 & Strong, fine, angular blocky \\
\hline $2 \mathrm{Bg} 3$ & $55-66$ & N 5 & Strong, fine, angular blocky \\
\hline $3 \mathrm{Bg} 4$ & $66-88$ & $\mathrm{~N} 4$ & Strong, fine, angular blocky \\
\hline $4 \mathrm{BC}$ & $88-105^{+}$ & 10YR 5/1 & Strong, fine, angular blocky \\
\hline
\end{tabular}


All statistical analyses were conducted using the $\mathrm{R}$ statistical software (R Core Team, 2020). Data were analyzed for normality of distribution and homogeneity of variance by the Shapiro-Wilk test (Shapiro and Wilk, 1965) and Bartlett's test (Bartlett, 1937), respectively, at $p<0.05$. The following parameters were calculated: minimum, maximum, mean, median, skewness, kurtosis, and coefficient of variation (CV). CV values were categorized according to criteria proposed by Pimentel-Gomes and Garcia (2002): CV < 10\%, low; $10<\mathrm{CV}<20 \%$, average; $20<\mathrm{CV}<30 \%$, high; and $\mathrm{CV}>30 \%$, very high.

Correlations between physical and hydraulic attributes of $\mathrm{A}$ and $\mathrm{B}$ horizons were determined by Pearson's correlation test at $p<0.05$. Hierarchical cluster analysis was performed using a hierarchical method, using Euclidean distance $(\%)$ as a measure of similarity between records and Ward's method, as clustering strategy. The grouping analysis was complemented with that of principal component analysis (PCA), that was used to reduce the dimensionality of the dataset without losing information and facilitate interpretation of data independence. According to Hongyu et al. (2015), PCA linearly combines variables of the original dataset into principal components (PCs). The first PC explains the greatest amount of variance in the dataset, and each successive PC explains less.

\section{RESULTS AND DISCUSSION}

Descriptive statistics of physical and hydraulic properties of A and B horizons along a toposequence in Rio de Janeiro, are presented in Table 2.

Table 2. Descriptive statistics of physical and hydraulic properties of surface and subsurface horizons along a toposequence in the coastal lowlands of Rio de Janeiro.

\begin{tabular}{|c|c|c|c|c|c|c|c|c|c|c|}
\hline \multirow{2}{*}{ Variable } & $\mathrm{PR}_{\mathrm{F}}$ & $\mathrm{PR}_{\mathrm{L}}$ & K & Macro & Micro & $\mathrm{Bd}$ & $\mathrm{GM}$ & Sand & Clay & Silt \\
\hline & \multicolumn{2}{|c|}{$\mathrm{MPa}$} & $\mathrm{cm} \mathrm{h}^{-1}$ & \multicolumn{2}{|c|}{$\%$} & $\mathrm{Mg} \mathrm{m}^{-3}$ & $\%$ & & $\mathrm{~g} \mathrm{~kg}^{-1}$ & \\
\hline \multicolumn{11}{|c|}{ A horizons } \\
\hline Minimum & 0.60 & 0.70 & 0.86 & 0.85 & 9.10 & 0.70 & 1.40 & 181.00 & 58.00 & 72.00 \\
\hline Mean & 1.08 & 1.43 & 35.00 & 23.18 & 20.52 & 1.15 & 9.80 & 631.30 & 234.81 & 133.88 \\
\hline Median & 1.20 & 1.30 & 24.15 & 28.28 & 12.00 & 1.25 & 10.25 & 742.50 & 151.50 & 109.50 \\
\hline Maximum & 1.50 & 2.40 & 99.20 & 31.08 & 47.70 & 1.40 & 18.30 & 861.00 & 578.00 & 242.00 \\
\hline $\mathrm{CV}(\%)$ & 34.47 & 43.42 & 100 & 41.97 & 75.20 & 21.41 & 63.09 & 44.79 & 91.48 & 50.93 \\
\hline Skewness & -0.33 & 0.44 & 0.62 & -1.27 & 1.22 & -0.62 & -0.21 & -0.92 & 0.94 & 0.84 \\
\hline Kurtosis & -1.33 & -1.63 & -1.10 & 0.28 & -0.48 & -1.07 & -1.61 & -0.87 & -0.84 & -0.97 \\
\hline W & $0.82^{\mathrm{ns}}$ & $0.88^{\mathrm{ns}}$ & $0.86^{\mathrm{ns}}$ & 0.68 & 0.64 & $0.86^{\mathrm{ns}}$ & $0.87^{\mathrm{ns}}$ & 0.72 & 0.73 & 0.76 \\
\hline \multicolumn{11}{|c|}{ B horizons } \\
\hline Minimum & 1.00 & 1.70 & 0.00 & 6.20 & 6.40 & 0.90 & 1.10 & 73.00 & 151.00 & 60.00 \\
\hline Mean & 2.63 & 4.18 & 9.33 & 18.45 & 22.14 & 1.27 & 17.29 & 456.00 & 430.40 & 113.62 \\
\hline Median & 2.45 & 2.90 & 3.30 & 18.55 & 18.77 & 1.30 & 13.90 & 532.00 & 373.50 & 115.50 \\
\hline Maximum & 5.00 & 8.80 & 30.50 & 28.50 & 46.09 & 1.60 & 39.90 & 687.00 & 824.00 & 163.00 \\
\hline $\mathrm{CV}(\%)$ & 61.07 & 58.61 & 58,60 & 46.10 & 60.20 & 19.73 & 82.90 & 53.37 & 58.89 & 33.18 \\
\hline Skewness & 0.097 & 0.79 & 1.27 & 0.84 & 0.57 & -0.27 & 0.70 & -0.84 & 0.70 & 0.70 \\
\hline Kurtosis & -2.08 & -0.96 & -0.47 & -0.69 & -1.28 & -0.69 & -0.82 & -0.90 & -0.84 & -1.19 \\
\hline$W$ & $0.87^{\mathrm{ns}}$ & $0.84^{\mathrm{ns}}$ & 0.65 & $0.90^{\text {ns }}$ & $0.80^{\mathrm{ns}}$ & $0.89^{\text {ns }}$ & $0.82^{\mathrm{ns}}$ & 0.78 & 0.81 & 0.78 \\
\hline
\end{tabular}

$\mathrm{PR}_{\mathrm{F}}$, field-measured penetration resistance; $\mathrm{PR}_{\mathrm{L}}$, laboratory-measured penetration resistance; $K$, hydraulic conductivity; Macro, macroporosity; Micro, microporosity; Bd, bulk density; GM, gravimetric moisture content; $\mathrm{CV}$, coefficient of variation; $W$, Shapiro-Wilk test; ns, not significant $(p>0.05)$. 
Soil physical and hydraulic properties showed an asymmetric distribution (Table 3). Fieldmeasured penetration resistance, macroporosity, and gravimetric moisture content in A horizons had negative skewness values, as bulk density and sand content in both horizons. This indicates a greater proportion of values above the mean. Other parameters had positive skewness, indicating that most values were below the mean. Symmetric distributions are those in which mean and median values are close to each other.

Table 3. Mean physical and hydraulic properties of surface and subsurface horizons along a toposequence in the coastal lowlands of Rio de Janeiro.

\begin{tabular}{|c|c|c|c|c|c|c|c|c|c|c|}
\hline \multirow{2}{*}{ Profile } & $\mathrm{PR}_{\mathrm{F}}$ & $\mathrm{PR}_{\mathrm{L}}$ & $K$ & Macro & Micro & $\mathrm{Bd}$ & GM & Sand & Clay & Silt \\
\hline & \multicolumn{2}{|c|}{$\mathrm{MPa}$} & $\mathrm{cm} \mathrm{h}^{-1}$ & \multicolumn{2}{|c|}{$\%$} & $\mathrm{Mg} \mathrm{m}^{-3}$ & $\%$ & \multicolumn{3}{|c|}{$\mathrm{g} \mathrm{kg}^{-1}$} \\
\hline \multicolumn{11}{|c|}{ A horizons } \\
\hline $\mathrm{P} 1$ & 1.3 & 2.3 & 86.3 & 27.9 & 14.2 & 1.1 & 14.3 & 226.5 & 636.5 & 137.0 \\
\hline $\mathrm{P} 2$ & 1.5 & 0.9 & 43.2 & 30.1 & 11.2 & 1.4 & 7.0 & 76.8 & 848.0 & 75.3 \\
\hline $\mathrm{P} 3$ & 0.6 & 0.9 & 10.5 & 29.5 & 10.4 & 1.4 & 1.5 & 59.0 & 858.3 & 82.8 \\
\hline P4 & 0.9 & 1.6 & 0.0 & 10.3 & 46.2 & 0.8 & 16.4 & 577.0 & 182.5 & 240.5 \\
\hline \multicolumn{11}{|c|}{ B horizons } \\
\hline $\mathrm{P} 1$ & 3.9 & 4.4 & 29.9 & 22.9 & 19.4 & 1.2 & 16.1 & 416.3 & 455.5 & 128.3 \\
\hline P2 & 4.4 & 7.9 & 3.2 & 14.2 & 17.2 & 1.6 & 12.1 & 330.5 & 608.3 & 61.3 \\
\hline P3 & 1.2 & 2.1 & 3.9 & 28.0 & 7.1 & 1.4 & 1.5 & 152.5 & 686.3 & 161.3 \\
\hline $\mathrm{P} 4$ & 1.0 & 2.3 & 0.3 & 8.7 & 44.8 & 0.9 & 39.5 & 822.3 & 74.0 & 103.8 \\
\hline
\end{tabular}

$\mathrm{PR}_{\mathrm{F}}$, field-measured penetration resistance; $\mathrm{PR}_{\mathrm{L}}$, laboratory-measured penetration resistance; $K$, hydraulic conductivity; Macro, macroporosity; Micro, microporosity; $\mathrm{Bd}$, bulk density; GM, gravimetric moisture content.

The Shapiro-Wilk test showed that most parameters were not normally distributed, with the exception of sand, clay, and silt contents in both horizons; macroporosity and microporosity in A horizons; and hydraulic conductivity in B horizons. However, according to Carvalho et al. (2002), theoretical skewness and kurtosis values close to 0 and 3, respectively, indicate a normal distribution. Therefore, variables showed a tendency to normality.

Bulk density in both horizons and silt content in B horizons had high CV values $(20<\mathrm{CV}$ $<30 \%$ ) (Pimentel-Gomes and Garcia, 2002). All other parameters had very high CV values (>30\%). In A horizons, the highest CV values (>60\%) were observed for moisture content, microporosity, clay content, and hydraulic conductivity, indicating heterogeneity along the toposequence. Such results are likely associated with the pedogenesis of the environments (Oliveira et al., 2015).

The sand content of A horizons ranged from $59.0 \mathrm{~g} \mathrm{~kg}^{-1}$ in P3 (Planossolo) to $577.0 \mathrm{~g} \mathrm{~kg}^{-1}$ in $\mathrm{P} 4$ (Gleissolo); moisture content, from $1.5 \%$ in $\mathrm{P} 3$ to $16.4 \%$ in P4; and microporosity, from $10.4 \%$ in P3 to $46.2 \%$ in P4 (Table 3). These high variations were observed despite the short distance between profiles (about $40 \mathrm{~m}$ ).

The PCA biplot presented in Figure 2A shows the distribution of physical and hydraulic attributes along axes 1 and 2. The two PCs explained together $92.20 \%$ of the variance in soil properties. PC1 explained $68.50 \%$ of the variance, and PC2 explained $23.70 \%$. The percentages of variance explained were higher than the minimum recommended for soil studies (Campos et $a l ., 2013)$. This means that the variability expressed within the sample perimeter has been sufficiently answered and expressed. 
(A)

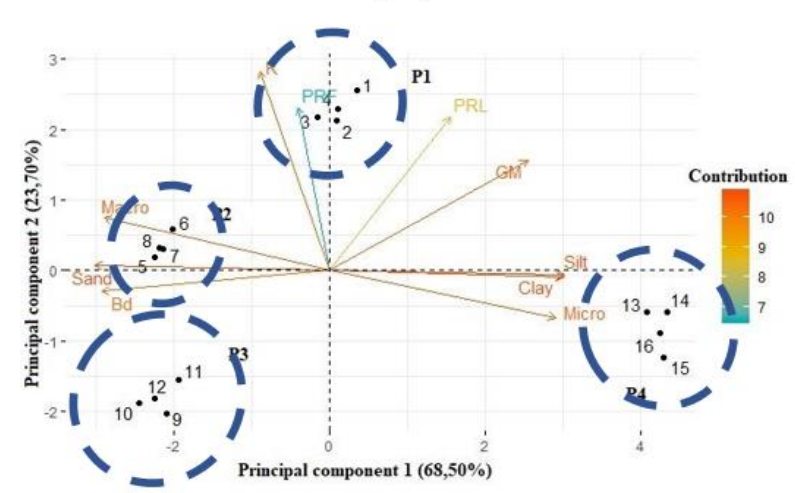

(B)

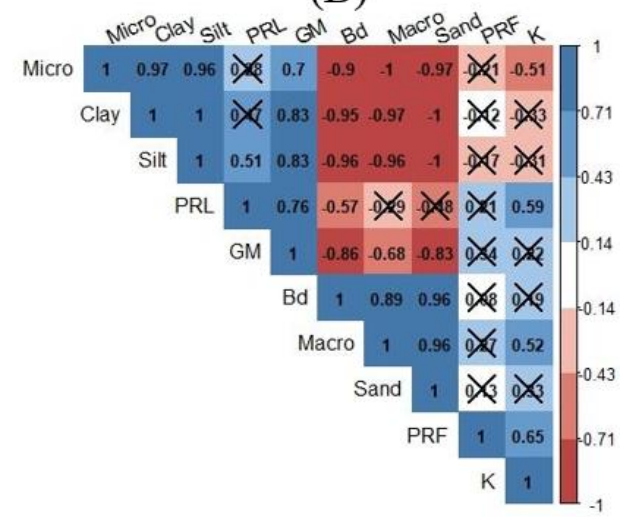

(C)

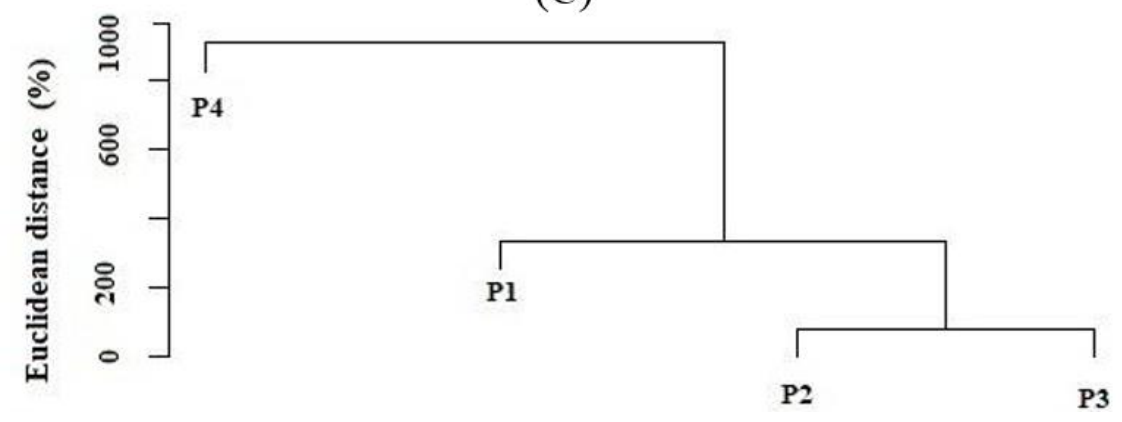

Figure 2. Principal component analysis biplot (A), Pearson correlation matrix (B), and Hierarchical cluster analysis for physical and hydraulic attributes of A horizons along a toposequence. P1-P4, soil profiles; Bd, bulk density; Macro, macroporosity; Micro, microporosity $\mathrm{GM}$, gravimetric moisture content; $K$, hydraulic conductivity; $\mathrm{PR}_{\mathrm{F}}$, field-measured penetration resistance; $\mathrm{PR}_{\mathrm{L}}$, laboratory-measured penetration resistance. Correlations marked with an $\mathrm{X}$ are not significant $(p<0.05)$.

Silt and clay content, and microporosity of A horizons were strongly associated with PC 1 with scores of high correlations of $0.99 ; 0.99 ; 0.96$, respectively (Figure 2A), and P4, probably because fine particle deposition is generally higher in lowlands than in slopes (Miotti et al., 2013; Santos et al., 2016). This phenomenon favors the formation of small pores (Miotti et al., 2013), which explains the high correlation $(r=0.97)$ between clay content and microporosity (Figure 2B). Although P4 was located near the water table, which would favor high moisture contents, and was associated with microporosity, gravimetric moisture content was not only associated with $\mathrm{P} 4$ but also with $\mathrm{P} 1$. The mean gravimetric moisture contents of $\mathrm{P} 1$ and $\mathrm{P} 4$ were similar (Table 3); however, GM showed a high positive correlation with PC1. The dark color of the A horizon of P1 can be attributed to its high organic carbon content (Table 1), as organic carbon favors the formation of a strongly developed granular structure, contributing to water retention (Loss et al., 2014; Rabot et al., 2018).

The profiles P2 and P3 were plotted on the negative side of PC1. These profiles, particularly P2, were related to sand content, bulk density, and macroporosity, with high negative scores correlations with PC1, $-0.99,-0.96,-0.95$, respectively (Figure 2A). Although $\mathrm{P} 2$ and $\mathrm{P} 3$ were positively associated with bulk density, the highest value was $1.4 \mathrm{Mg} \mathrm{m}^{-3}$ (Table 3 ), lower than that considered critical for crop root development (Reichert et al., 2009; Collares et al., 2011). Macroporosity and sand content were strongly correlated ( $r=0.96)$ (Figure 2B), whereas macroporosity and hydraulic conductivity were moderately correlated $(r=0.54)$ (Figure 2B). Even though macropores facilitate the flow of water in soil, hydraulic conductivity was more associated with P1, with high positive correlation, 0.93 with PC2 (Figure 2A). This result is probably due to the strongly developed granular structure of $\mathrm{P} 1$, contributing to the regulation of water infiltration and retention in the soil (Rabot et al., 2018). These findings 
reinforce the importance of determining the morphological characteristics of soil horizons in physical-hydraulic studies. Field- and laboratory-measured penetration resistances were associated with P1, but values were not high enough to affect root development (Costa et al., 2012; Drescher et al., 2012). Both parameters contributed little to the variance in soil properties of A horizons.

For the cluster analysis for A horizon along the toposequence (Figure 2C), the formation of three large groups with a connection distance of around $1000 \%$ was observed. In this horizon, P4 distanced itself $(\sim 1000 \%)$ from the other profiles forming an isolated group, while the profile P1 with dissimilarity of approximately $400 \%$, formed a second group; profiles P2 and P3 joined in a third group with a maximum distance between them of approximately $100 \%$.

PCA of physical and hydraulic properties of B horizons revealed two PCs, which together explained $85.80 \%$ of the variance in the dataset. PC1 explained $57.10 \%$ of the variance; and PC2, 28.70\% (Figure 3A). P4 was plotted far from other profiles, on the negative side of PC1, and was associated with clay content, microporosity, and gravimetric moisture content, with high score correlations, $-0.98,-0.99$ and -0.99 , respectively. These parameters were almost 2fold higher than those of the other profiles (Table 3). Such results are attributed to the high deposition of silt in lowlands and the proximity to the water table.

(A)

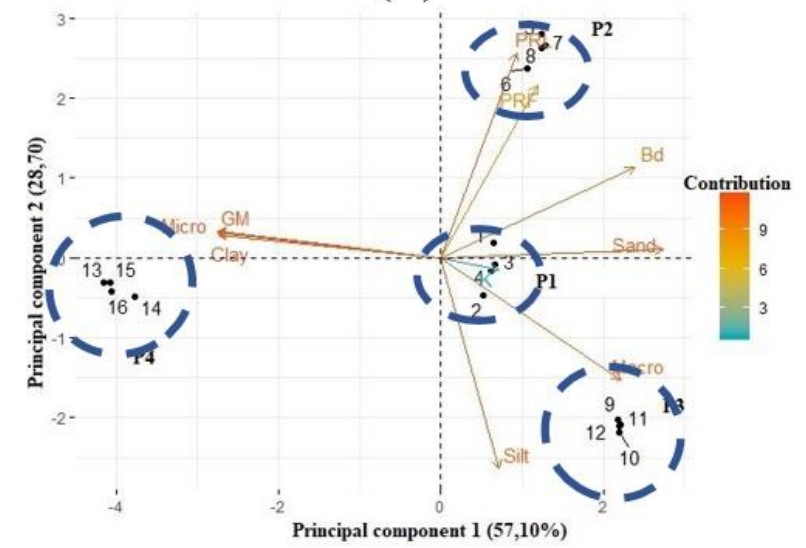

(B)

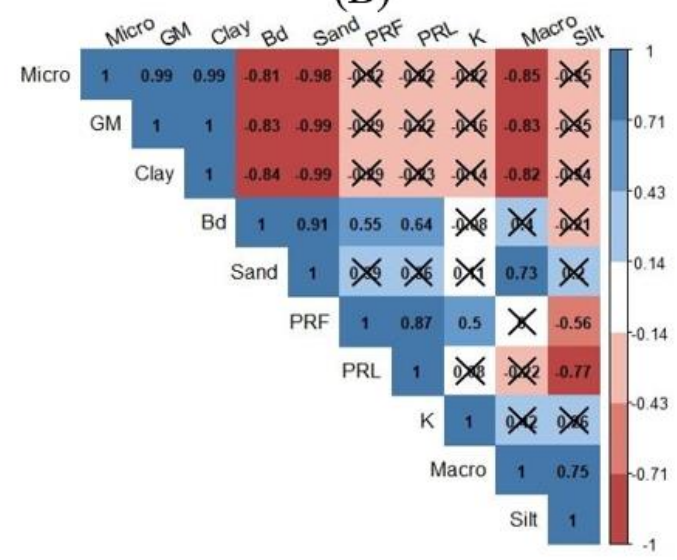

(C)

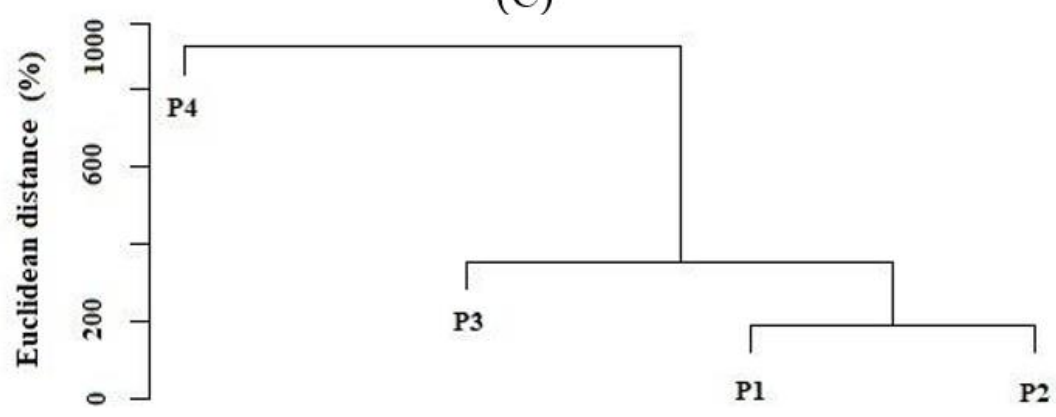

Figure 3. Principal component analysis biplot (A), Pearson correlation matrix (B), and Hierarchical cluster analysis for physical and hydraulic attributes of B horizons along a toposequence. P1-P4, soil profiles; Bd, bulk density; Macro, macroporosity; Micro, microporosity GM, gravimetric moisture content; $K$, hydraulic conductivity; $\mathrm{PR}_{\mathrm{F}}$, field-measured penetration resistance; $\mathrm{PR}_{\mathrm{L}}$, laboratory-measured penetration resistance. Correlations marked with an X are not significant $(p<$ $0.05)$.

Correlations between microporosity, moisture content, and clay content were very strong, ranging from 0.99 to 1 (Figure 3B). Hydraulic conductivity was negatively associated with $\mathrm{P} 4$, in agreement with the low value observed in the profile $\left(0.3 \mathrm{~cm} \mathrm{~h}^{-1}\right)$. The parameter was more associated with P1 because of the profile's well-developed structure. Nevertheless, hydraulic 
conductivity contributed little to the PCs, with the highest correlation value associated with the PC1 (0.25).

Sand content was related to P2 and P3, as both profiles had similar sand contents, with high positive scores correlation with PC1 (0.98). However, macroporosity was more strongly associated with $\mathrm{P} 3$ and $\mathrm{PC} 1$, with positive score correlation of 0.79 . Silt content was also associated with P3; silt and sand contents in P3 added to $850 \mathrm{~g} \mathrm{~kg}^{-1}$, whereas, in P2, the sum of silt and sand fractions was $670 \mathrm{~g} \mathrm{~kg}^{-1}$. Furthermore, silt and macroporosity were strongly correlated $(r=0.75)$, explaining the high association between macroporosity and P3.

Laboratory-measured penetration resistance was higher than field-measured resistance in all B horizons, but parameters were strongly correlated $(r=0.87)$. Penetration resistance was associated with $\mathrm{P} 2$, in which resistance values were considered critical to root development (Costa et al., 2012; Drescher et al., 2012). Although bulk density was moderately correlated with laboratory-measured $(r=0.64)$ and field-measured $(r=0.55)$ penetration resistance, the parameter was also associated with P2. These parameters were correlated positively with the PC2, 0.92 and 0.77 , respectively. The mean bulk density in P2 was $1.6 \mathrm{Mg} \mathrm{m}^{-3}$. The high bulk density and penetration resistance observed in P2 is likely associated with translocation and deposition of clay in the pores of subsurface layers, as evidenced by the difference in clay contents between A and B horizons (76.8 and $330.5 \mathrm{~g} \mathrm{~kg}^{-1}$, respectively). The densification process is responsible for increasing root penetration resistance (Cortez et al., 2011), which explains the association of penetration resistances with $\mathrm{P} 2$. The $\mathrm{Bd}$ showed a positive correlation with PC1 (0.85).

For the cluster analysis for A horizon along the toposequence (Figure 3C), the formation of three large groups with a connection distance of around $1000 \%$ was observed. In this horizon, P4 distanced itself $(\sim 1000 \%)$ from the other profiles forming an isolated group, while the profile P3 with dissimilarity of approximately $400 \%$, formed a second group; profiles P1 and $\mathrm{P} 2$ joined in a third group with a maximum distance between them of approximately $100 \%$.

\section{CONCLUSIONS}

1. Soil physical and hydraulic properties vary greatly along short slopes, particularly hydraulic conductivity, moisture content, microporosity, and clay content.

2. The high variability in soil physical and hydraulic attributes can be explained by differences in clay content, microporosity, and silt content in A horizons and clay content, microporosity, and moisture content in B horizons.

3. An increase in clay content with depth leads to an increase in density and penetration resistance.

4. Among the profiles analyzed, P4 showed greater dissimilarity from the others, for both depths studied.

\section{REFERENCES}

ALAGNA, V.; BAGARELlO, V.; DI PRIMAS, S.; IOVINO, MASSIMO. Determining hydraulic properties of a loam soil by alternative infiltrometer techniques. Hydrological Process, v. 30, p. 263-275, 2016. https://doi.org/10.1002/hyp.10607

ALVARES, C. A; STAPE, J. L.; SENTELHAS, P. C.; DE MORAES, G.; LEONARDO, J.; SPAROVEK, G. Köppen's climate classification map for Brazil. Meteorologische Zeitschrift, v. 22, n. 6, p. 711-728, 2013. https://doi.org/10.1127/0941-2948/2013/0507

BARTLETT, M. S. Properties of sufficiency and statistical tests. Proceedings of the Royal Society of London, v. 160, p. 268-282, 1937. https://doi.org/10.1098/rspa.1937.0109 
CAMBARDELLA, C. A; MOORMAN, T. B.; NOVAK, J. M.; PARKIN, T. B.; KARLEN, D. L.; TURCO, R. F.; KONOPKA, A. E. Field-scale variability of soil properties in central Iowa soils. Soil Science Society of America Journal, v. 58, p. 1501-1511, 1994. https://doi.org/10.2136/sssaj1994.03615995005800050033x

CAMPOS, M. C. C.; RIBEIRO, M. R.; SOUZA JUNIOR, V. S.; RIBEIRO FILHO, M. R.; AQUINO, R. E.; OLIVEIRA, I. A. Superfícies geomórficas e atributos do solo em uma topossequência de transição Várzea-Terra Firme. Bioscience Journal, v. 29, n. 5, p. 132$142,2013$.

CARVALHO, J. R. P.; SILVEIRA, P. M.; VIEIRA, S. R. Geoestatística na determinação da variabilidade espacial de características químicas do solo sob diferentes preparos. Pesquisa Agropecuária Brasileira, v. 37, p. 1151-1159, 2002. https://doi.org/10.1590/S0100-204X2002000800013

COELHO, M. R.; MARTINS, V. M.; TORRADO, P. V.; SOUZA, C. R. de G.; Perez, X. L. O.; VÁZQUEZ, F. M. Relação solo-relevo-substrato geológico nas restingas da planície costeira do estado de São Paulo. Revista Brasileira de Ciência do Solo, v. 34, p. 833846, 2010. https://doi.org/10.1590/S0100-06832010000300025

COLlARES, G. L.; REINERT, D. J.; REICHERT, J. M.; KAISER, D. R. Compactação superficial de Latossolos sob integração lavoura: pecuária de leite no noroeste do Rio Grande do Sul. Ciência Rural, v. 41, n. 2, p. 246-250, 2011. https://doi.org/10.1590/S0103-84782011000200011

CORTEZ, J. W.; ALVES, A. D. S.; MOURA, M. R. D. M.; OLSZECSKI, N.; NAGAHAMA, H. J. Atributos físicos do Argissolo Amarelo do semiárido nordestino sob sistemas de preparo. Revista Brasileira de Ciência do Solo, v. 35, n. 4, p. 1207-1216, 2011. https://doi.org/10.1590/S0100-06832011000400014

COSTA, M. A. T.; TORMENA, C. A.; LUGÃO, S. M. B.; FIDALSKI, J.; NASCIMENTO, W. G. D.; MEDEIROS, F. M. D. Resistência do solo à penetração e produção de raízes e de forragem em diferentes níveis de intensificação do pastejo. Revista Brasileira de Ciência do Solo, v. 36, n. 3, p. 993-1004, 2012. https://doi.org/10.1590/S010006832012000300029

DRESCHER, M. S.; ELTZ, F. L. F.; DENARDIN, J. E.; FAGANELLO, A.; DRESCHER, G. L. Resistência à penetração e rendimento da soja após intervenção mecânica em latossolo vermelho sob plantio direto. Revista Brasileira de Ciência do Solo, v. 36, n. 6, p. 18361844, 2012. https://doi.org/10.1590/S0100-06832012000600018

FERREIRA, C. R.; SILVA NETO, E. C.; PEREIRA, M. G.; NASCIMENTO GUEDES, J.; ROSSET, J. S.; ANJOS, L. H. C. Dynamics of soil aggregation and organic carbon fractions over 23 years of no-till management. Soil \& Tillage Research, v. 198, p. 104533, 2020. https://doi.org/10.1016/j.still.2019.104533

HICKMANN, C.; COSTA, L. M.; SCHAEFER, C. E. G. R.; FERNANDES, R. B. A.; ANDRADE, C. D. L. T. Atributos físico-hídricos e carbono orgânico de um Argissolo após 23 anos de diferentes manejos. Revista Caatinga, v. 25, n. 1, p. 128-136, 2012. https://periodicos.ufersa.edu.br/index.php/caatinga/article/view/2114/pdf 
HONGYU, K.; SANDANIELO, V. L. M.; OLIVEIRA JUNIOR, G. J. Principal Component Analysis: theory, interpretations and applications. Engineering and Science, v. 1, n. 5, p. 83-90, 2015. https://doi.org/10.18607/ES20165053

LOSS, A.; PEREIRA, M. G.; COSTA, E. M.; BEUTLER, S. J. Frações granulométricas e oxidáveis de matéria orgânica sob diferentes sistemas de uso do solo, no Paraná, Brasil. $\begin{array}{lllllll}\text { Bioscience Journal, } & \text { v. } & 30, & \text { n. } & 1, & 2014 .\end{array}$ http://www.seer.ufu.br/index.php/biosciencejournal/article/view/15041/13681

MIOTTI, A. A.; COSTA, M. C. G.; FERREIRA, T. O.; ROMERO, R. E. Profundidade e atributos físicos do solo e seus impactos nas raízes de bananeiras. Revista Brasileira de Fruticultura, v. 35, n. 2, p. 536-545, 2013. https://doi.org/10.1590/S010029452013000200024

MUEHE, D.; LIMA, C. F.; BARROS, F. M. L. Rio de Janeiro. In: MUEHE, D. Erosão e Progradação do Litoral Brasileiro. Brasília: Ministério do Meio Ambiente, 2006. v. 1, p. 265-296.

OLIVEIRA, I. A.; CAMPOS, M. C. C.; FREITAS, L.; SOARES, M. D. R. Caracterização de solos sob diferentes usos na região sul do Amazonas. Acta Amazônica, v. 45, n. 1, p. 1 12, 2015. https://doi.org/10.1590/1809-4392201400555

PAVÃO, L. L.; SANCHES, L.; PINTO JÚNIOR, O. B.; SPOLADOR, J. The influence of litter on soil hydro-physical characteristics in na area of Acuri palm in the Brazilian Pantanal. $\begin{array}{lllllll}\text { Ecohydrology } \quad \text { \& } & \text { Hydrobiology, } & \text { v. } & 19, & \text { p. }\end{array}$ https://doi.org/10.1016/j.ecohyd.2019.04.004

PIMENTEL-GOMES, F.; GARCIA, C. H. Estatística aplicada a experimentos agronômicos e florestais. 1. ed. Piracicaba: FEALQ, 2002. 309 p.

R CORE TEAM. R: A language and environment for statistical computing. Vienna, 2020.

RABOT, E.; WIESMEIER, M.; SCHLÜTER, S.; VOGEL, H. J. Soil structure as an indicator of soil functions: a review. Geoderma, v. 314, p. 122-137, 2018. https://doi.org/10.1016/j.geoderma.2017.11.009

REICHERT, J. M.; SUZUKI, L. E. A. S.; REINERT, D. J.; HORN, R.; HÅKANSSON, I. Reference bulk density and critical degree-of-compactness for no-till crop, production in subtropical highly weathered soils. Soil \& Tillage Research, v. 102, n. 2, p. 242-254, 2009. https://doi.org/10.1016/j.still.2008.07.002

SANTOS G. L.; PEREIRA, M. G.; LIMA, S. S.; CEDDIA, M. B.; MENDONÇA, V. M. M.; DELGADO, R. C. Landform curvature and its effect on the spatial variability of soil attributes, Pinheiral-RJ/BR, Cerne, v. 22, p. 431-438, 2016. https://doi.org/10.1590/01047760201622042184

SANTOS, H. G.; JACOMINE, P. K. T.; ANJOS, L. H. C.; OLIVEIRA, V. A.; LUMBRERAS, J. F.; COELHO, M. R.; ALMEIDA, J. A.; ARAÚJO FILHO, J. C.; OLIVEIRA, J. B.; CUNHA, T. J. F. Sistema Brasileiro de Classificação de Solos. 5. ed. Brasília: Embrapa; 2018. 356 p.

SANTOS, R. D.; SANTOS, H. G.; KER, J. C.; ANJOS, L. H. C.; SHIMIZU, S. H. Manual de descrição e coleta de solo no campo. 7. ed. Viçosa,MG: SBCS, 2015. 100 p. 
SOUZA, S. O.; VALE, C. C. do. Environmental Vulnerability of the Caravelas (BA) Coastal Plain as Subsidy to Environmental Planning. Sociedade \& Natureza, v. 28: p. 147-160, 2016. https://doi.org/10.1590/1982-451320160110

SHAPIRO, S. S.; WILK, M. B. An analysis of variance test for normality (complete samples). Biometrika, v. 52, p. 591-611, 1965. https://doi.org/10.2307/2333709

STEFANOSKI, D. C.; SANTOS, G. G.; MARCHÃO, R. L.; PETTER, F. A.; PACHECO, L. P. Uso e manejo do solo e seus impactos sobre a qualidade física. Revista Brasileira de Engenharia Agrícola e Ambiental, v. 17, n. 12, p.1301-1309, 2013. https://doi.org/10.1590/S1415-43662013001200008

STOLF, R. Theory and test of formulas for transforming impact penetrometer data in soil resistence. Revista brasileira de Ciência do Solo, v. 15, p. 229-235, 1991.

TEIXEIRA, P. C.; DONAGEMMA, G. K.; FONTANA, A.; TEIXEIRA, W. G. Manual de Métodos de Análise de Solo. 3.ed. Brasília: Embrapa; 2017. 575 p. 